\title{
Voltammetric Determination of Sulfaclozine Sodium at Sephadex-modified Carbon Paste Electrode
}

\author{
Emad Mohamed Hussien, ${ }^{1,{ }^{*}}$ Hanaa Saleh, ${ }^{2}$ Magda El Henawee, ${ }^{2}$ \\ Afaf Abou El Khair ${ }^{2}$ and Neven Ahmed ${ }^{1}$ \\ ${ }^{1}$ National Organization for Drug Control and Research (NODCAR), Giza, Egypt. \\ ${ }^{2}$ Faculty of Pharmacy, Zagazig University, Zagazig, Egypt. \\ *Corresponding author: E-mail: emadhussien@yahoo.com \\ Tel.: +2 0237496077
}

Received: 11-08-2019

\begin{abstract}
The electrochemical behavior of Sulfaclozine Sodium (SLC) was studied at a bare and sephadex-modified carbon paste electrodes by cyclic voltammetry and square wave voltammetry. The cyclic voltammetry (CV) showed a well-defined irreversible oxidation peak at $0.94 \mathrm{~V}$ in Britton- Robinson buffer $\mathrm{pH}$ 7.0. The strong affinity of SLC to sephadex allowed accumulation of SLC at the surface of electrode and thus higher electrochemical sensitivity to SLC. The influence of sephadex loading, the $\mathrm{pH}$ of the solution and the scan rate on the peak current was studied. A linear calibration curve covering the concentration range from 0.005 to $1 \mathrm{mM}$ was obtained using SWV. The method was successfully applied for the determination of SLC in the veterinary pharmaceutical formulations with satisfactory accuracy and precision.
\end{abstract}

Keywords: Sulfaclozine Sodium; square wave voltammetry; sephadex; carbon paste electrode.

\section{Introduction}

Coccidiosis is a parasitic disease that attacks the intestinal tract of poultry caused by protozoan parasites of the genus Eimeria. This disease is of worldwide occurrence and costs the poultry industry many millions of dollars every year to control. ${ }^{1}$ Although live vaccines were introduced, prophylactic chemotherapy is still preferred for coccidiosis control in most countries. The last half of the twentieth century marked improvements in the performance of commercially reared poultry. These improvements would not be possible without the introduction of a succession of ever more effective anticoccidial agents to control coccidiosis. ${ }^{2}$

Sulfaclozine, $\mathrm{N}^{1}$ - (6-chloropyrazinyl) sulfanilamide (Figure 1) is a sulfonamide antibacterial that has been used<smiles>Nc1ccc(S(=O)(=O)Nc2cncc(Cl)n2)cc1</smiles>

Figure 1. Chemical structure of Sulfaclozine in veterinary medicine. ${ }^{3}$ it is effective in the treatment of clinical coccidiosis as well as prevention of the disease. ${ }^{4}$

The analytical methods which have been reported for the determination of sulfaclozine include chromatographic methods with different detectors. ${ }^{5-9}$ and capillary electrophoresis. ${ }^{10}$ These methods are either time-consuming or use expensive instrumentation.

In contrast to the reported techniques, the voltammetric techniques are simple and rapid with high sensitivity and selectivity for drug analysis. Moreover, the carbon paste electrodes which are used for voltammetric measurements have several advantages for the electrochemical investigation of organic compounds. They are cheap, easy to prepare and use; and offer surface regeneration and modification, low background current, a large potential domain, no memory effects and adsorption-extraction capabilities. ${ }^{11,12}$ Furthermore, including surfactants in the experimental protocol and modification of the carbon paste (chemically or by nanomaterials) have been reported to influence the electrochemical process occurring at the surface of the electrode. ${ }^{13,14}$ Sephadex is a cross-linked dextran which is used as a stationary phase in gel filtration chromatography. ${ }^{15}$ Carbon paste electrodes modified with 
sephadex have been used for the sensitive determination of nifuroxazide and glibenclaide. ${ }^{16,17}$ Indeed, Numerous pharmaceutical compounds were analyzed using carbon paste electrodes.

The present work reports for the first time a SWV method for the determination of SLC in veterinary formulation. The proposed method utilizes the electrochemical oxidation of SLC at a carbon paste electrode modified with sephadex in a micellar medium. The effect of sephadex on the oxidation peak current was investigated. The method was validated According to the ICH guidelines. ${ }^{18}$

\section{Experimental}

\section{1. Reagents and Materials}

Sulfaclozine sodium was obtained from Yangzhou Tianhe Pharmaceutical Co., LTD, China with potency 99.75\%. Clozicocc ${ }^{\circledR}$ W.S.P (Each $100 \mathrm{~g}$ contains $32 \mathrm{~g}$ sulfaclozine sodium) was obtained from Pharco Pharmaceuticals, Alex., Egypt. Graphite powder, paraffin oil, Sephadex G-50, C18 silica gel and chitosan were supplied from Sigma-Aldrich. Methanol was purchased from Loba Chemie Co., India. Sodium dodecyl sulfate (SDS), Phosphoric acid and boric acid were supplied from Adwic Co., Egypt. Acetic acid was obtained from Piochem Co., Egypt. Briton Robinson buffer (BR) buffer was prepared by adding equal volumes of phosphoric acid $0.04 \mathrm{M}$, acetic acid $0.04 \mathrm{M}$ and boric acid $0.04 \mathrm{M}$, the $\mathrm{pH}$ of the buffer was adjusted by $\mathrm{NaOH} 0.2 \mathrm{M}$ to cover the $\mathrm{pH}$ range from 2.0 to 10.0. SDS $10.0 \mathrm{mM}$ was prepared by dissolving an appropriate amount of SDS in water. Double- distilled water was used throughout the study and referred to by "water".

\section{1. 4. Standard Solution}

Sulfaclozine stock solution $(10.0 \mathrm{mM})$ was prepared by dissolving $30.66 \mathrm{mg}$ of SLC in $1.0 \mathrm{~mL}$ methanol, then diluting with water to $10 \mathrm{~mL}$.

\section{2. Apparatus}

Bio-logic SP 150 electrochemical work station with a three-electrode configured stand (model C-3) was used for the voltammetric measurements. The working electrode was a bare carbon paste electrode or a sephadex-modified carbon paste electrode (SMCPE); the reference electrode was $\mathrm{Ag} / \mathrm{AgCl} / 3 \mathrm{M} \mathrm{KCl}$ (BAS, USA) and the counter electrode was a platinum wire (BAS, USA).

\section{3. Procedures}

\section{3. 1. Preparation of Modified Carbon- Paste Electrode}

Sephadex-modified carbon paste (SMCPE) electrode was made by hand mixing of $0.4 \mathrm{~g}$ Sephadex and $0.8 \mathrm{~g}$ of graphite powder with $0.4 \mathrm{~mL}$ paraffin oil. Plain (unmodified) carbon paste was made by mixing $1.0 \mathrm{~g}$ graphite powder with $0.6 \mathrm{~mL}$ paraffin oil. The paste was packed into the electrode body and smoothed on a filter paper till a shiny appearance of the electrode surface was obtained.

\section{3. 2. Analytical Procedure}

The CV at the carbon paste was repeated between 0 and $1.4 \mathrm{~V}$ several times in the buffer solution ( $\mathrm{pH} 7.0)$ till the $\mathrm{CV}$ becomes stable. Then the electrode was transferred into another cell containing BR buffer solution ( $\mathrm{pH} 7.0$ ), $0.005 \mathrm{mM}$ to $1.0 \mathrm{mM}$ SLC and $0.03 \mathrm{mM}$ SDS. The solution was stirred for $30 \mathrm{~s}$ at an open circuit potential, afterwards, the $\mathrm{CV}$ was recorded between +0.4 and +1.4 , at $100 \mathrm{mVs}^{-1}$ scan rate.

\section{3. 3. Calibration Curve of SLC}

The SWV was performed to determine SLC in bulk powder and pharmaceutical formulations. Different aliquots were accurately transferred from the stock standard solution to an electrochemical cell containing $10 \mathrm{~mL}$ buffer ( $\mathrm{pH} 7.0)$ and $0.03 \mathrm{mM}$ SDS. The SWV was recorded at SMCPE. The peak current was plotted against drug concentration of SLC in $(\mu \mathrm{M})$.

\section{3. 4. Application to Veterinary Pharmaceutical Formulation}

An accurately weighed $0.96 \mathrm{~g}$ Clozicocc $^{\circledR}$ W.S.P. containing $306.7 \mathrm{mg}$ of sulfaclozine sodium was transferred into a $100-\mathrm{mL}$ volumetric flask and dissolved in $10 \mathrm{~mL}$ methanol. The solution was sonicated for $15 \mathrm{~min}$, then, the flask was completed to the mark with water to obtain 10.0 mM SLC (solution I). Further dilution was carried out from solution 1 into $10-\mathrm{mL}$ volumetric flask to obtain 1.0 mM SLC (solution II).

The accuracy and precision of the method was studied using $0.005,0.47$ and $0.65 \mathrm{mM}$ of the sample solution, each solution was prepared in triplicate. The accuracy and precision solutions were prepared by transferring $50 \mu \mathrm{L}$ from solution 1; $500 \mu \mathrm{L}$ and $700 \mu \mathrm{L}$ from solution II, each into an electrochemical cell containing BR pH 7 and 0.03 $\mathrm{mM}$ SDS. The concentration of the sample was determined by the standard addition method using the SWV.

\section{Results and Discussion}

\section{1. Sulfaclozine Electrochemical Oxidation Behavior}

The electrochemical behavior of SLC was studied at the carbon paste by recording the $\mathrm{CV}$ from 0 to $1.4 \mathrm{~V}$ in $\mathrm{BR}$ $\mathrm{pH}$ 7. The CV (Figure 2) shows one anodic peak current 


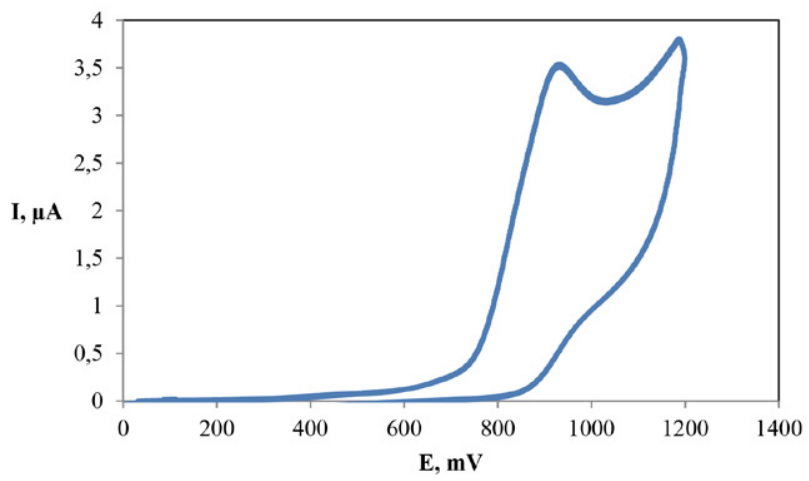

Figure 2. The results are the average of five separate determinations Cyclic voltammogram of $0.1 \mathrm{mM}$ SLC in BR buffer of $\mathrm{pH} 7.0$ at a bare carbon paste lectrode.

$((\mathrm{Ip})=3.5 \mu \mathrm{A}$ at $0.94 \mathrm{~V})$ with no cathodic peak in the reverse scan, it means that the oxidation process of SLC is irreversible. The anodic peak could be due to the oxidation of the amine group in SLC. ${ }^{19}$

\section{2. Optimization of the Experimental Conditions}

\section{2. 1. Effect of $\mathrm{pH}$}

The electrochemical oxidation of organic compounds depends, in most cases, on the $\mathrm{pH}$ of the solution. Herein, the effect of changing the $\mathrm{pH}$ of the solution on the oxidation of SLC was studied in BR buffer over the $\mathrm{pH}$ range from 2.0-10.0. It was observed that the peak potential of SLC is shifted towards less positive values when the $\mathrm{pH}$ was increased. The relationship between the $\mathrm{E}_{\mathrm{p}}$ and $\mathrm{pH}$ at the sephadex-modified carbon paste electrode was found to be linear and controlled by the equation $\mathrm{E}_{\mathrm{P}}=$ $-51 \mathrm{pH}+1284\left(\mathrm{R}^{2}=0.995\right)$ (Figure 3a). The slope $(\sim 51$ $\mathrm{mV}$ per $\mathrm{pH}$ ) is close to the expected $59 \mathrm{mV}$ per $\mathrm{pH}$ indicating that equal number of protons and electrons involved in the oxidation process of SLC. The highest oxidation current was obtained at $\mathrm{pH} 7$ (Figure $3 \mathrm{~b}$ ), therefore, all measurements were carried out at $\mathrm{pH}$ 7.0.

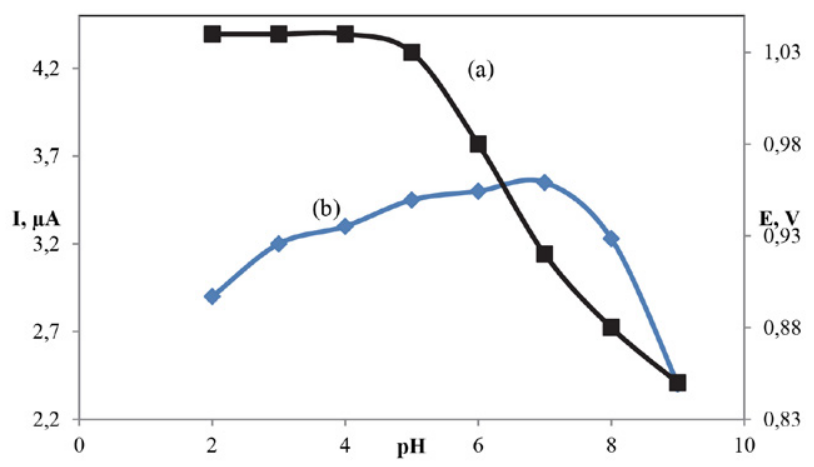

Figure 3. Dependence of peak potential (a) and peak current $(\mathbf{b})$ on The $\mathrm{pH}$ of $0.1 \mathrm{mM}$ SLC. The scan rate is $100 \mathrm{mV} \mathrm{s}^{-1}$

\section{2. 2. Effect of Sephadex}

Different materials including $\mathrm{C}_{18}$ modified silica, chitosan and sephadex were tested for possible enhancement of the oxidation current and, hence, increasing sensitivity of the electrode. (Figure 4) shows no difference in the electrochemical behavior of sulfaclozine when $30 \%$ $\mathrm{C}_{18}$ modified silica was added to the carbon paste electrode, while the addition of $30 \%$ chitosan to the paste make a little improvement in the current response. In contrast, carbon paste modified with $30 \%(\mathrm{w} / \mathrm{w})$ sephadex exhibited a considerable oxidation current that indicating the high affinity of the drug to sephadex. This affinity has been utilized for preconcentration of the drug onto the electrode surface to increase the sensitivity to SLC. The effect of sephadex loading on the peak current is shown in Figure 5.

\section{2. 3. Effect of Sodium Dodecyl Sulfate}

Sulfaclozine oxidation behavior in a micellar medium was also studied using SDS.

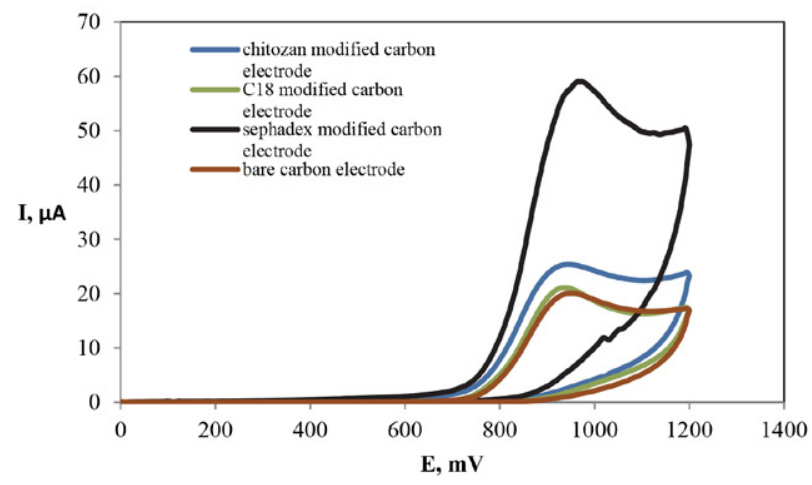

Figure 4. Cyclic voltammograms of $1.0 \mathrm{mM}$ SLC in PH 7.0 using different modified and unmodified electrodes.

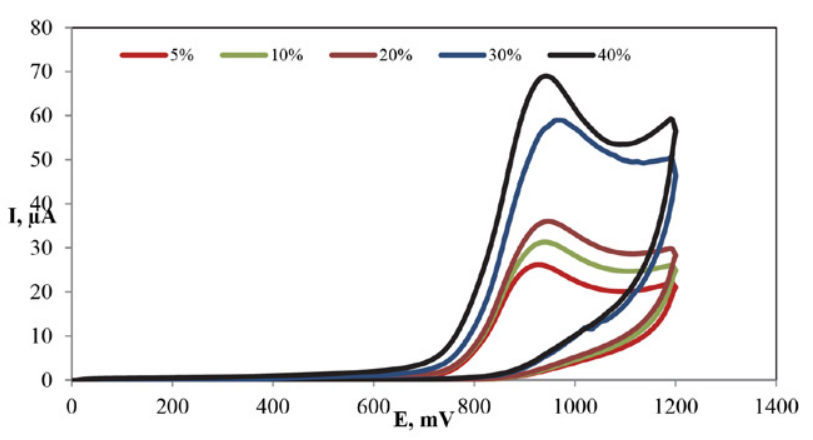

Figure 5. Cyclic voltammograms of SLC $(1.0 \mathrm{mM})$ in PH 7.0 at carbon paste electrode containing different amounts of sephadexL; the scan rate is $100 \mathrm{mV} \mathrm{s}^{-1}$

SDS is a hydrophobic ionic surfactant, which can be adsorbed onto the electrode surface. As a result, the electrochemical process such as the mass and electron transfer energy at the electrode/solution interface are affected. ${ }^{20}$ It 


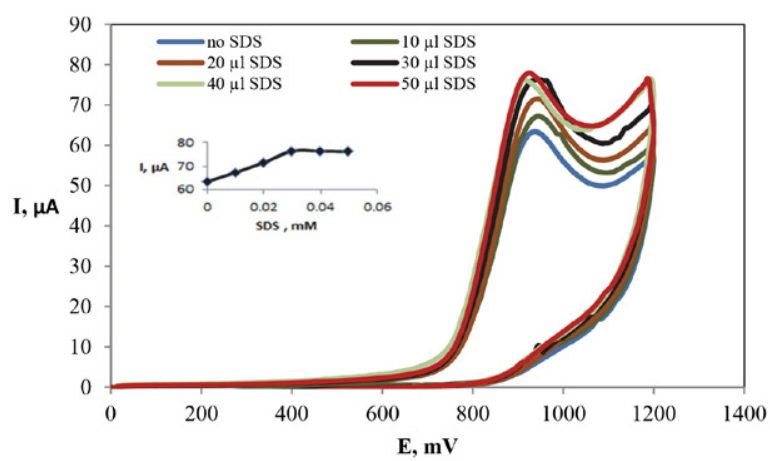

Figure 6. Cyclic voltammograms recorded in $1.0 \mathrm{mM}$ SLC containing different concentrations of SDS, the measurements were carried out using $40 \%$ sephadex carbon paste electrode in BR buffer $\mathrm{pH}$ 7.0.

has been reported that SDS can remove the oily binder (insulator) and hence lower the uncompensated resistance at the electrode/solution interface. ${ }^{21,22,23}$ Herein, the effect of SDS was studied by the addition of different volume of $0.01 \mathrm{M}$ SDS $(10-50 \mu \mathrm{L})$ to the SLC solution of $\mathrm{pH} 7$ and recording the CV. Figure 6 shows the relationship between the anodic current and the SDS concentrations. It was observed that the peak current increases with increasing SDS in the measuring solution, and the highest oxidation current was observed when the SLC solution contains $30 \mu \mathrm{L}$ of $0.01 \mathrm{M}$ SDS; no further improvement in the peak current was observed above this concentration.

\section{2. 4. Effect of Scan Rate}

The effect of the scan rate $(v)$ on the peak potential $\left(E_{\mathrm{p}}\right)$ and the peak current $\left(i_{\mathrm{p}}\right)$ was studied between 10 $\mathrm{mVs}^{-1}$ and $250 \mathrm{mVs}^{-1}$ in $1.0 \mathrm{mM}$ sulfaclozine solution in BR buffer ( $\mathrm{pH} 7.0$ ) containing $0.03 \mathrm{mM}$ SDS (Figure 7a), The relationship between the oxidation peak current of SLC and the square root of scan rate $\left(v^{1 / 2}\right)$ was found to be linear, indicating that electrochemical oxidation of SLC is a diffusion controlled process. ${ }^{24}$

Plotting the logarithm of the peak current against the logarithm of the scan rate resulted in a straight line with a slope of 0.47 (Figure 7b), this value is close to the theoretical value of 0.5 for a purely diffusion-controlled process. ${ }^{24}$ It was also found that the $\mathrm{E}_{\mathrm{p}}$ (oxidation peak potential) was dependent on scan rate, the peak potential was shifted to more positive values when the scan rate increased, which confirms that the oxidation process is irreversible. Furthermore, the relationship between the peak potential and the logarithm of the scan rate was found to be linear (Figure $7 \mathrm{C}$ ) in accordance with Laviron's equation (1). ${ }^{25}$

$$
\mathrm{E}_{\mathrm{p}}=\mathrm{E}^{0^{\prime}}+\left(\frac{2.303 \mathrm{RT}}{\alpha \mathrm{nF}}\right) \log \left(\frac{\mathrm{RTk} 0}{\alpha \mathrm{nF}}\right)+\left(\frac{2.303 \mathrm{RT}}{\alpha \mathrm{nF}}\right) \log v
$$

Here $\alpha$ is the transfer coefficient, $\mathrm{k}^{0}$ is the standard heterogeneous rate constant of the reaction, $v$ is the scan
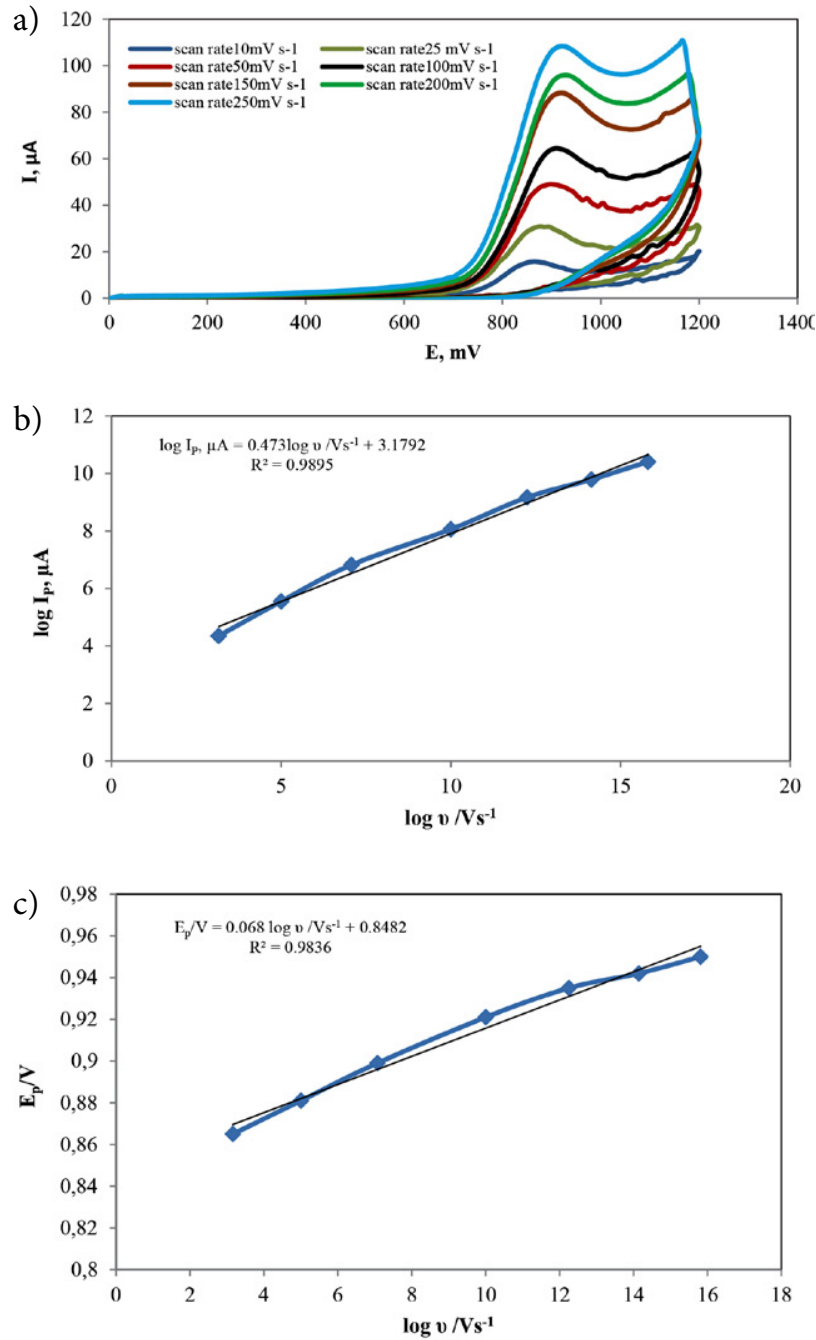

Figure 7. (a) The CV of $1.0 \mathrm{mM}$ SLC containing $0.03 \mathrm{mM}$ SDS in BR buffer of $\mathrm{pH} 7.0$ at $40 \%$ SMCPE at different scan rates, (b) Dependence of the logarithm of peak current Ip/ $\mu \mathrm{A}$ on logarithm of scan rate $\left(v / \mathrm{Vs}^{-1}\right)$. (c) Relationship between peak potential $\mathrm{E}_{\mathrm{p}} / \mathrm{V}$ and logarithm of scan rate $\log \left(\mathrm{v} / \mathrm{Vs}^{-1}\right)$.

rate, and $\mathrm{E}_{0}$ is the formal redox potential, $\mathrm{n}$ is the number of electrons transferred. So, the value of an can be obtained from the slope of Ep vs log $v$. The slope was found to be 0.068 , when $\mathrm{T}=298 \mathrm{~K}$ and $\mathrm{R}=8.314 \mathrm{JK}^{-1} \mathrm{~mol}^{-1}$ and $\mathrm{F}=$ $96485 \mathrm{C} / \mathrm{mol}$, an was found to be 0.85 . According to Bard and Faulkner. ${ }^{26} \alpha$ can be calculated from the following equation (2).

$$
\alpha=\frac{47.7}{\mathrm{Ep}-\mathrm{Ep} / 2} \mathrm{mV}
$$

$\mathrm{k}^{0}$ value can be calculated from the intercept of the above plot if the value of $\mathrm{E}^{0^{\prime}}$ is known.

$\mathrm{E}^{0^{3}}$ in Eq. (1) can be obtained from the intercept of Ep versus $v$ curve by extrapolating to the vertical axis at $v$ $=0^{27}$. All values of an, $\alpha, \mathrm{n}, \mathrm{E}^{0^{3}}$ and $\mathrm{k}^{0}$ are summarized in table 1 . 
Table 1. The calculated values of an, $\alpha, n, \mathrm{E}^{0^{3}}$ and $\mathrm{k}^{0}$ for the electro-oxidation of SLC by cyclic voltammetry (CV) at SMCPE.

\begin{tabular}{cc}
\hline Parameters & SMCPE \\
\hline an & 0.8476 \\
$\alpha$ & 0.611 \\
$\mathrm{n}$ & 1.38 \\
$\mathrm{E}^{0}$ & 0.85 \\
$\mathrm{k}^{0}$ & 3.1439 \\
\hline
\end{tabular}

\section{2. 5. Square Wave Voltammetry (SWV)}

Under optimal experimental conditions, the calibration curve was constructed using the SWV over the concentration range from 0.005 to $1 \mathrm{mM}$. The parameters of SWV are $50 \mathrm{mV}$ pulse height, $200 \mathrm{~ms}$ pulse width, $10 \mathrm{~ms}$ step height and $100 \mathrm{~ms}$ step time. The solution was stirred for $30 \mathrm{~s}$ at $400 \mathrm{rpm}$ at an open circuit potential followed by 30 s quiescent time before any measurements.

\section{3. Calibration, Detection Limit and Reproducibility}

A linear relationship between SLC anodic peak current of and its concentration was found in the concentra-
Table 2. Performance data of the proposed SWV method for determination of SLC

\begin{tabular}{cc}
\hline Parameters & SLC \\
\hline Linearity range $(\mathrm{mM})$ & $0.005 \mathrm{mM}$ to $1.0 \mathrm{mM}$ \\
Slope $\left(\mu \mathrm{A} . \mathrm{mM}^{-1}\right)$ & 50.67 \\
Intercept $(\mu \mathrm{A})$ & 5.86 \\
Correlation coefficient $(\mathrm{r})$ & 0.9995 \\
LOD $(\mu \mathrm{M})$ & 1.04 \\
LOQ $(\mu \mathrm{M})$ & 2.99 \\
Accuracy $(\mathrm{mean} \pm$ S.D. $)$ & $100.18 \pm 0.01$ \\
Precision $(\mathrm{RSD} \%)$ & \\
Interday & 2.08 \\
Intraday & 2.12 \\
\hline
\end{tabular}

tion range from $0.005 \mathrm{mM}$ to $1.0 \mathrm{mM}(\mathrm{R}=0.999)$ with a slop of $50.67 \mu \mathrm{AmM}^{-1}$ and a limit of detection $0.001 \mathrm{mM}$. The reproducibility (\%RSD, $\mathrm{n}=3$ ) of the peak current for $0.005 \mathrm{mM}$ sulfaclozine was $2.08 \%$ as shown in Table 2.

\section{4. Determination of Sulfaclozine in Veterinary Formulation}

SLC was determined in Clozicocc $^{\circledR}$ W.S.P. using standard addition method; the obtained results were sta-

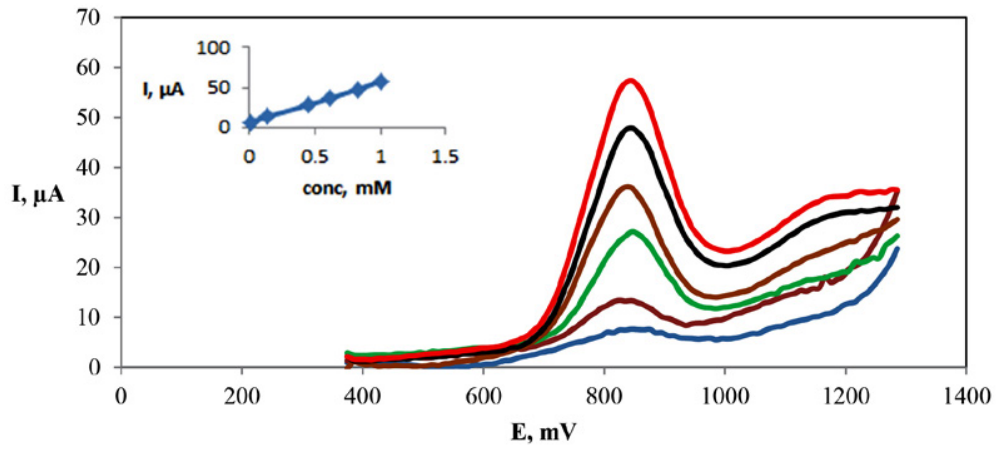

Figure 8. SWV of SLC over the concentration range from 0.005 to $1.0 \mathrm{mM}$ in BR pH 7.0 containing $0.03 \mathrm{mM}$ SDS using $40 \%$ SMCPE.

Table 3. determination of SLC in pharmaceutical dosage form and statistical comparison of the proposed voltammetric and the published HPLC method ${ }^{5}$

\begin{tabular}{|c|c|c|c|c|c|}
\hline \multirow{2}{*}{$\begin{array}{l}\text { Pharmaceutical } \\
\text { formulation }\end{array}$} & \multicolumn{4}{|c|}{ Standard addition technique } & \multirow{2}{*}{$\begin{array}{c}\text { Reference } \\
\text { method }^{5}\end{array}$} \\
\hline & Taken(mg) & Added (mg) & Found(mg) & \%Recovery ${ }^{a}$ & \\
\hline \multirow{3}{*}{$\begin{array}{l}\text { Clozicocc w.s.p } \\
\text { batch No.564 }\end{array}$} & 0.015 & 0.015 & 0.0149 & 99.96 & \\
\hline & 0.120 & 1.45 & 1.43 & 98.87 & \\
\hline & 0.120 & 2.00 & 2.01 & 100.31 & \\
\hline Mean & & & & 99.59 & 99.33 \\
\hline S.D & & & & 1.01 & 1.51 \\
\hline $\mathrm{n}$ & & & 5 & & \\
\hline variance & & & & 1.02 & 2.28 \\
\hline $\begin{array}{l}\text { Student's } t \text {-test } \\
(2.132)^{\mathrm{b}}\end{array}$ & & & & 0.64 & - \\
\hline F-test $(6.39)^{b}$ & & & & 2.24 & - \\
\hline
\end{tabular}

a The results are the average of five separate determinations ${ }^{\mathrm{b}}$ the tabulated $t$ and $F$ values, respectively, at $P=0.05$ 
tistically compared with those obtained by a reference method. ${ }^{5}$ The calculated $\mathrm{t}$ - and F-values are found to be less than the theoretical ones, confirming that accuracy and precision of the two methods are comparable at $95 \%$ confidence level (Table 3).

\section{Conclusion}

Herein, we report for the first time a novel simple and rapid SWV method for SLC determination in veterinary formulations. The method is based on a carbon paste electrode modified with sephadex. The sephadex modified carbon paste electrode showed a dramatic increase in the oxidation peak current over the plain carbon paste. The SWV method was linear over a wide concentration range of SLC from $0.005 \mathrm{mM}$ to $1.0 \mathrm{mM}$ with a detection limit of $1 \mu \mathrm{M}$. The method was applied successfully for the determination of SLC in the veterinary formulation with satisfactory accuracy and precision. The student's t-test and F-ratio test showed no significant difference regarding the accuracy and precision between the present method and the reported method.

\section{List of abbreviations}

SLC : $\quad$ Sulfaclozine Sodium

SWV : Square wave voltammetry

SDS : $\quad$ Sodium dodecyl sulfate

BR: $\quad$ Briton Robinson buffer

SMCPE : Sephadex-modified carbon paste electrode CV : $\quad$ Cyclic Voltammetry

W.S.P : Water soluble powder

\section{References}

1. Chapman, H. D., Chapter 53 - Coccidiosis in Egg Laying Poultry, in Egg Innovations and Strategies for Improvements, P.Y. Hester, Editor. 2017, Academic Press: San Diego. 571-579. DOI:10.1016/B978-0-12-800879-9.00053-6

2. Chapman, H.D., Perspectives for the control of coccidiosis in poultry by chemotherapy and vaccinationin Proceedings of the IXth International Coccidiosis Conference. 2005. Foz de Iguassu, Parana, Brazil. 99-104.

3. S. C. Sweetman, R.P.S., Martindale: The Complete Drug Reference. thirty-eights ed. Vol. 1. 2014, London: Pharmaceutical Press.

4. Md. Harun-Or-Rashid, et al., Scholars Journal of Agriculture and Veterinary Sciences, 2016, 3(4), 284-287.

5. TANG Shu, C. J., GAO Jian-long, BAO En-dong, Nanjing Agricultural Univeristy, 2012, 105-109.

6. Yu, H., et al., Journal of Chromatography B, 2011, 879(25), 2653-2662. DOI:10.1016/j.jchromb.2011.07.032

7. Bousova, K. Senyuva, and H. Mittendorf, Journal of Chromatography A, 2013, 1274, 19-27.

DOI:10.1016/j.chroma.2012.11.067

8. Gorissen, B., et al., Analytical and Bioanalytical Chemistry, 2015, 407(15), 4447-4457. DOI:10.1007/s00216-014-8449-5

9. Goodspeed, et al., Journal - Association of Official Analytical Chemists, 1978, 61(5), 1050-1053.

10. Su, H. X., et al., Fenxi Ceshi Xuebao, 2013, 32(2), 156-161.

11. Ivan Švancara, et al.,Electroanalysis with Carbon Paste Electrodes. 2012: CRC Press Taylor \& Francis Group. DOI: $10.1201 / \mathrm{b} 11478$

12. Kalcher, K., et al., Electroanalysis, 1995, 7(1), 5-22. DOI:10.1002/elan.1140070103

13. Acuna, J. A., et al., Talanta, 1993, 40(11), 1637-42. DOI:10.1016/0039-9140(93)80078-6

14. R.Vittal, H. Gomathi, and K. J. Kim, Adv Colloid Interface Sci, 2006, 119(1), 55-68. DOI:10.1016/j.cis.2005.09.004

15. Gel Filtration, Theory and Practice, Pharmacia Fine Chemicals. 1976, Uppsala: Sweden.

16. Radi. A, Analytical and bioanalytical chemistry, 2004, 378, 822-6. DOI:10.1007/s00216-003-2392-1

17. Radi. A, Fresenius' Journal of Analytical Chemistry, 1999, 364, 590-594. DOI:10.1007/s002160051391

18. ICH Q2A. validation of analytical methods. International Conference on Harmonization. 2003, IFPMA: Geneva.

19. V. Momberg, et al., Analytica Chimica Acta, 1984, 159, 119127. DOI:10.1016/S0003-2670(00)84288-9

20. Sanghavi, B. J. and A. K. Srivastava, Electrochimica Acta, 2010, 55(28), 8638-8648. DOI:10.1016/j.electacta.2010.07.093

21. Jayaprakash, G. K., et al., Journal of Molecular Liquids, 2017, 240, 395-401. DOI:10.1016/j.molliq.2017.05.093

22. Manjunatha JG, et al., Int J Electrochem Sci, 2009, 4, 662-671.

23. Shankar, S. S., B. E. K. Swamy, and B. N. Chandrashekar, Journal of Molecular Liquids, 2012, 168, 80-86.

DOI:10.1016/j.molliq.2012.01.012

24. D. K. Gosser, Cyclic Voltammetry; Simulation and Analysis of Reaction Mechanisms. New York (N.Y.): VCH, 1993.

25. E. Laviron, J. Electroanal. Chem. 1979, 101(1), 19-28. DOI:10.1016/S0022-0728(79)80075-3

26. A. J. Bard and L. R. Faulkner, "Electrochemical Methods Fundamentals and Applications," 2nd Edition, Wiley, Hoboken, 2004.

27. Wu, Y., X. Ji, and S. Hu, Bioelectrochemistry. 2004, 64, 91-97. DOI:10.1016/j.bioelechem.2004.03.005 


\section{Povzetek}

Elektrokemijsko obnašanje natrijevega sulfaklozina (SLC) je bilo proučevano na golih in sephadex-modificiranih elektrodah iz ogljikove paste s ciklično voltametrijo in kvadratno valovno voltametrijo. Ciklična voltametrija $(\mathrm{CV})$ je pokazala dobro definiran nepovratni vrh oksidacije pri $0.94 \mathrm{~V}$ v Britton-Robinson pufru pri pH 7.0. Močna afiniteta SLC do sefadeksa je omogočila kopičenje SLC na površini elektrode in s tem večjo elektrokemično občutljivost za SLC. Proučen je bil vpliv nalaganja sefadeksa, $\mathrm{pH}$ raztopine in hitrost skeniranja na največji tok. Z uporabo SWV smo dobili linearno kalibracijsko krivuljo, ki pokriva območje koncentracije od 0.005 do $1 \mathrm{mM}$. Metodo smo uspešno uporabili za določanje SLC v veterinarskih farmacevtskih formulacijah $\mathrm{z}$ zadovoljivo točnostjo in natančnostjo. 